\title{
Modeling and assessment of a multi-apartment residential house with a planned overhaul
}

\author{
Rustam Fatullaev ${ }^{1, *}$ \\ ${ }^{1}$ Moscow State University of Civil Engineering, 26 Yaroslavskoe shosse, Moscow, 129337, Russia
}

\begin{abstract}
The overhaul potential is an effective mathematical model for evaluating organizational and technological solutions when planning for an overhaul of apartment buildings. The purpose of the study is to create a tool that would allow using the potential of the overhaul of tenants of an apartment building. The difficulty of using the potential of overhaul is the need to transform the qualitative characteristics of a dwelling house before the overhaul will be carried out in quantitative terms. But even after obtaining the value of the overhaul potential, it is necessary to obtain an interpretation of the obtained quantitative indicators in qualitative characteristics. To describe the object in which the overhaul is planned, taking into account all the parameters that may affect the choice of work in quantitative terms, it is necessary to form an organizational and technological model of a residential building in which an overhaul is planned. In turn, in order to interpret the obtained quantitative value of the potential, it is necessary to form a private potential scale.
\end{abstract}

\section{Introduction}

The principles for assessing organizational and technological decisions during the overhaul of apartment buildings do not take into account all the possible parameters that affect the efficiency of repair work.

The use of the overhaul potential developed in previous studies allows taking into account the polyparametric characteristics of the object [1] where the overhaul is planned. The method of calculating the potential helps to determine the necessary list of work on the overhaul and the priority sequence of work when planning overhaul [2]. A feature of the use of potential is that the results obtained from the application of the potential are presented in quantitative form.

The potential of organizational-technological processes of construction production were studied and integrated by such scientists as A. Lapidus, D. Topchiy, A. Goncharov, A. Makarov, P. Govorukha.

\footnotetext{
* Corresponding author: angela-1309.m@yandex.ru
} 
Due to the fact that the main consumer is a resident of an apartment building, the purpose of the study is to create a system in which the input and output data using the potential will be intuitive for the user.

\section{Methods}

A system is a set of elements that are in relationships and relationships with each other, which forms a certain integrity, unity [3-4]. In our case, the system includes tools for modeling and evaluating the resulting model.

A model is an abstract representation of an object in mathematical form, designed to represent certain aspects of this object and provides answers to the questions being studied [5-6]. Organizational and technological systems are formed using the functional and systemic approach. The organizational-technological system consists of separate, but interrelated elements - subsystems [6]. A subsystem is a set of system elements interconnected and performing a relatively independent task (several tasks) related to the goal of achieving the goals of the system [6-7].

For the case proposed in the case study, the organizational-technological system includes eight subsystems [2]. As a result, the main task is to identify subsystems with certain limitations that ensure the achievement of goals. Subsystems are presented as an integral part of the system and allow you to achieve a local result [6], which leads to a general result. It is required to determine the functional purpose of each subsystem and determine their limitations [6].

Scaling methods are special techniques for transforming qualitative characteristics into some quantitative variable (numerical system).

The scaling process is as follows:

- at the stage of data collection, an empirical system of the objects under study is created and the type of relationship between them is fixed (the type of information depends);

- at the stage of data analysis, a numerical system is built that modulates the relationships of the empirical system of objects (the amount of information depends);

Scaling methods solve two types of tasks:

- numerical display of the aggregate of objects using their average rating (using the rating scales);

- numerical display of the internal characteristics of objects by fixing their relationship to a phenomenon (using the scale of settings).

\section{Results}

The input parameters of the system are a set of data obtained from various sources and various methods: visual inspection, measuring instruments, etc [2]. Using the "logical chain method", it is possible to analyze the presented source data and distribute them on the appropriate scale, but first we need to determine the weights of the parameters.

Using the variational series method, weights of parameters are determined $[8,9]$. The total weight is 1 . Data is taken from the ranking table [2]

At the first stage, the arithmetic average of a number of variations is calculated:

$$
\bar{u}=\frac{1}{m} \sum_{i=1}^{m} y_{i} n_{i}
$$

where $y_{i}$ - points that are set for the $i$-th parameter; $n_{i}$ - number of the $i$-th, which is set by the group of experts to the $i$-th parameter; $\mathrm{m}$ - number of expert groups.

Then all parameters are summed up: 


$$
U=\sum_{j=1}^{p} \bar{u}=\sum_{j=1}^{p} \frac{1}{m} \sum_{i=1}^{m} y_{i} n_{i}
$$

where $U$ - sum of the arithmetic means of the variational series.

At the third stage, the weight of each parameter is determined:

$$
W_{i}=\frac{\frac{1}{m} \sum_{i=1}^{m} y_{i} n_{i}}{U}
$$

Using data from previous studies [2], weighted values were obtained. The results are presented in the table of weights of parameters (Table 1).

Table 1. Parameter group weights.

\begin{tabular}{|c|l|l|l|l|l|l|c|}
\hline$W_{\mathbf{1}}\left(\boldsymbol{x}_{\mathbf{1}}\right)$ & $\boldsymbol{W}_{\mathbf{2}}\left(\boldsymbol{x}_{\mathbf{2}}\right)$ & $\boldsymbol{W}_{\mathbf{3}}\left(\boldsymbol{x}_{\mathbf{3}}\right)$ & $\boldsymbol{W}_{\mathbf{4}}\left(\boldsymbol{x}_{\mathbf{4}}\right)$ & $\boldsymbol{W}_{\mathbf{5}}\left(\boldsymbol{x}_{\mathbf{5}}\right)$ & $\boldsymbol{W}_{\mathbf{6}}\left(\boldsymbol{x}_{\mathbf{6}}\right)$ & $\boldsymbol{W}_{\mathbf{7}}\left(\boldsymbol{x}_{\mathbf{7}}\right)$ & $\boldsymbol{W}_{\mathbf{8}}\left(\boldsymbol{x}_{\mathbf{8}}\right)$ \\
\hline 0.25 & 0.19 & 0.14 & 0.13 & 0.11 & 0.08 & 0.06 & 0.04 \\
\hline
\end{tabular}

After analyzing the data obtained, we can conclude that the parameter $x_{2}$ has the greatest influence, and the parameter $x_{8}$ has the least impact.

The open nature of the mathematical model allows an indefinite number of levels [11].

In this case, the following condition must be fulfilled: for the adequacy of the mathematical model, the process must give the total value of the levels of the model parameters in accordance with the established control points in accordance with the experiment plan.

$$
P_{U .0 .}=T D_{U . O .} \leq 92
$$

According to the data from previous studies [2], there are control points of the plan [2] where in the point of the plan U1, in all groups of parameters, the indicators of the upper levels of significance are established [2], $P_{U . O} .=92$

In the point of the plan U16, in all groups of parameters, the indicators of lower levels of significance are established [2], $P_{U . O}=43,56$

In the point of the plan $\mathrm{U} 25$, in all groups of parameters, the indicators of the main (zero) significance levels are set [2], $P_{U . O .}=54$

Accordingly, we set various levels of the parameters of the organizational-technological model: the lower one - 43.56; medium - 54.0; the top one is 92 . In this case, the model allows building a function for approximation of the regression curve [12-13].

Given the above, we will complete table 2.

Table 2. The levels of the parameters of the organizational and technological model of the facility overhaul and their values.

\begin{tabular}{|l|c|l|l|}
\hline $\begin{array}{l}\text { Parameter } \\
\text { name }\end{array}$ & $\begin{array}{l}\text { Parameter } \\
\text { symbol }\end{array}$ & Parameter levels & Parameter value \\
\hline $\begin{array}{l}\text { Energy } \\
\text { efficiency of } \\
\text { enclosing } \\
\text { structures }\end{array}$ & $x_{1}\left(P_{1}\right)$ & $\begin{array}{l}\text { The deviation of the value of the } \\
\text { actual specific annual } \\
\text { consumption of energy resources } \\
\text { from the base level is more than }+ \\
50 \%\end{array}$ & 0.0 \\
\cline { 3 - 4 } & & from + 50 inclusive to + 25 & 16.65 \\
\cline { 3 - 4 } & & from + 25 inclusive to 0 & 33.27 \\
\cline { 3 - 4 } & from 0 inclusive to - 15 & 43.56 \\
\hline & from - 15 inclusive to - 30 & 53.23 \\
\hline & from - 30 inclusive to - 40 & 59.89 \\
\cline { 3 - 4 } & from - 40 inclusive to - 50 & 66.24 \\
\cline { 3 - 4 } & from - 50 inclusive to - 60 & 78.98 \\
\cline { 3 - 4 } & -60 inclusive and less & 92 \\
\hline Physical & $x_{2}\left(P_{2}\right)$ & The state is dilapidated, PD 61- & 0.0 \\
\hline
\end{tabular}




\begin{tabular}{|c|c|c|c|}
\hline \multirow{6}{*}{$\begin{array}{l}\text { deterioration } \\
\text { of structures }\end{array}$} & & \multicolumn{2}{|l|}{$70 \%$} \\
\hline & & $\begin{array}{l}\text { Unsatisfactory condition (below } \\
\text { average), PD } 41-60 \%\end{array}$ & 15.33 \\
\hline & & Not quite satisfactory, PD $31-40 \%$ & 43.56 \\
\hline & & Satisfactory, PD 21-30\% & 48.11 \\
\hline & & It is quite satisfactory, PD $11-20 \%$ & 76.23 \\
\hline & & Good, PD $0-10 \%$ & 92 \\
\hline \multirow{6}{*}{$\begin{array}{l}\text { Physical } \\
\text { deterioration } \\
\text { of } \\
\text { engineering } \\
\text { networks and } \\
\text { equipment }\end{array}$} & \multirow[t]{6}{*}{$x_{3}\left(P_{3}\right)$} & $\begin{array}{l}\text { The state is dilapidated, PD } 61- \\
70 \%\end{array}$ & 0.0 \\
\hline & & $\begin{array}{l}\text { Unsatisfactory condition (below } \\
\text { average), PD } 41-60 \%\end{array}$ & 15.33 \\
\hline & & Not quite satisfactory, PD $31-40 \%$ & 46 \\
\hline & & Satisfactory, PD 21-30\% & 61.33 \\
\hline & & It is quite satisfactory, PD $11-20 \%$ & 76.66 \\
\hline & & Good, PD 0-10\% & 92 \\
\hline \multirow[t]{5}{*}{ Security level } & \multirow[t]{5}{*}{$x_{4}\left(P_{4}\right)$} & $\begin{array}{l}\text { The security system is not in an } \\
\text { emergency state }\end{array}$ & 0 \\
\hline & & $\begin{array}{l}\text { The presence of one of the } \\
\text { complex security systems (fire } \\
\text { alarm) }\end{array}$ & 23 \\
\hline & & $\begin{array}{l}\text { The presence of two of the } \\
\text { complex security systems (fire } \\
\text { alarm systems, dispatching } \\
\text { systems, storage and display of } \\
\text { information) }\end{array}$ & 43.56 \\
\hline & & $\begin{array}{l}\text { The presence of four of the } \\
\text { complex security systems (fire } \\
\text { alarm systems, dispatching } \\
\text { systems, monitoring of } \\
\text { engineering networks at home) }\end{array}$ & 69 \\
\hline & & $\begin{array}{l}\text { The presence of five of the } \\
\text { complex security systems (alarms, } \\
\text { scheduling systems, monitoring, } \\
\text { access control and rapid response) }\end{array}$ & 92 \\
\hline \multirow{4}{*}{$\begin{array}{l}\text { The } \\
\text { complexity of } \\
\text { the methods } \\
\text { used to assess } \\
\text { the state of } \\
\text { the residential } \\
\text { house }\end{array}$} & \multirow{4}{*}{$x_{5}\left(P_{5}\right)$} & Without applying any techniques & 0 \\
\hline & & Visual inspection & 43.56 \\
\hline & & Instrumental inspection & 61.32 \\
\hline & & Technical inspection & 92 \\
\hline \multirow[t]{4}{*}{$\begin{array}{l}\text { Obsolescence } \\
\text { of structures }\end{array}$} & \multirow[t]{4}{*}{$x_{6}\left(P_{6}\right)$} & $\begin{array}{l}\begin{array}{l}\text { Significant loss of practical } \\
\text { significance, OS } 36-45 \%\end{array} \\
\end{array}$ & 0 \\
\hline & & $\begin{array}{l}\text { Some loss of practical } \\
\text { significance, OS } 26-35 \%\end{array}$ & 43.56 \\
\hline & & $\begin{array}{l}\text { Average obsolescence, OS } 15- \\
25 \%\end{array}$ & 61.32 \\
\hline & & Minor obsolescence, OS 0-15\% & 92 \\
\hline \multirow{4}{*}{$\begin{array}{l}\text { Obsolescence } \\
\text { of } \\
\text { engineering } \\
\text { networks and } \\
\text { equipment }\end{array}$} & \multirow[t]{4}{*}{$x_{7}\left(P_{7}\right)$} & $\begin{array}{l}\text { Lack of hot and cold water } \\
\text { supply, garbage chute, elevator } \\
\text { equipment, telephone } \\
\text { communication), OS } 36-45 \%\end{array}$ & 0 \\
\hline & & $\begin{array}{l}\text { Lack of hot water supply, garbage } \\
\text { chute, elevator equipment, } \\
\text { telephone communication), OS } \\
26-35 \%\end{array}$ & 43.56 \\
\hline & & $\begin{array}{l}\text { Lack of hot water supply, garbage } \\
\text { chute), OS } 16-25 \%\end{array}$ & 61.32 \\
\hline & & $\begin{array}{l}\text { Perhaps the absence of a garbage } \\
\text { chute and telephone), OS } 0-15 \%\end{array}$ & 92 \\
\hline $\begin{array}{l}\text { Consumer } \\
\text { quality of } \\
\text { residential }\end{array}$ & $x_{8}\left(P_{8}\right)$ & $\begin{array}{l}\text { There are significant deviations } \\
\text { from the stated consumer quality } \\
\text { of residential house }\end{array}$ & 0 \\
\hline
\end{tabular}




\begin{tabular}{|l|l|l|l|}
\hline house & $\begin{array}{l}\text { There are minor deviations from } \\
\text { the stated consumer quality }\end{array}$ & 43.56 \\
\cline { 2 - 4 } & $\begin{array}{l}\text { Consumer quality of residential } \\
\text { house corresponds to the stated }\end{array}$ & 68.7 \\
\cline { 2 - 3 } & $\begin{array}{l}\text { Consumer quality of residential } \\
\text { house above declared }\end{array}$ & 92 \\
\hline
\end{tabular}

As a result, it became possible to build a graph (Figure 1), which shows an ideal model of the object where unscheduled overhaul is planned, and the scales of the parameters correspond to their weight. The graph presented in (Figure 1) is cumulative.

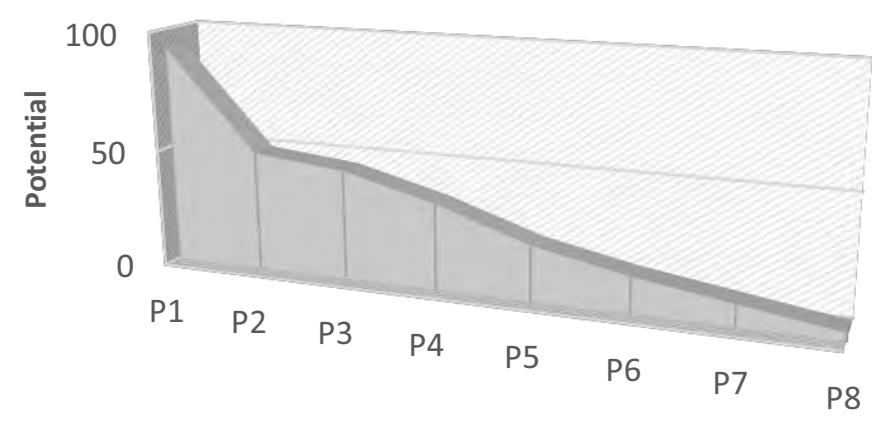

Fig. 1. Graphic interpretation of the ideal model of the facility overhaul.

For a comprehensive assessment of the resulting potential, it was decided to develop a private psychophysical scale based on the Harrington scale of desirability.

Table 3. Harrigton's Psychophysical Desirability Scale.

\begin{tabular}{|c|c|}
\hline Desirability & $\begin{array}{c}\text { Marks on the scale of } \\
\text { desirability }\end{array}$ \\
\hline Very good & $1.00-0.79$ \\
\hline Good & $0.80-0.64$ \\
\hline Satisfactory & $0.63-0.37$ \\
\hline Bad & $0.36-0.20$ \\
\hline Very bad & $0.19-0.00$ \\
\hline
\end{tabular}

A private psychophysical scale was constructed using data from values of the various levels of the parameter of the organizational-technological model. Those values of the potential of unscheduled repairs that are below the "Satisfactory" mark indicate that the proposed organizational and technological model is unsatisfactory [14-15].

Table 3. Private Psychophysical Desirability Scale.

\begin{tabular}{|c|c|}
\hline $\begin{array}{c}\text { Psychophysical } \\
\text { assessment }\end{array}$ & Potential values \\
\hline Very good & $80-92$ \\
\hline Good & $63-79.99$ \\
\hline Satisfactory & $43.57-62.99$ \\
\hline Unsatisfactory & $0-43.56$ \\
\hline
\end{tabular}


After drawing up a private scale of the desirability of the potential of unscheduled repairs, it became possible to give a qualitative assessment of the organizationaltechnological model.

The obtained method of modeling and evaluation was tested on an apartment building. Baseline data of a residential building: nine floors, a residential building with a total area of $14,350 \mathrm{~m} 2$; year of construction 1979; floors: reinforced concrete; frame: panel; foundation: concrete pillars; energy efficiency class: D.

Table 4. Levels of parameters of the organizational and technological model

\begin{tabular}{|c|c|c|c|}
\hline Parameter name & $\begin{array}{l}\text { Parameter } \\
\text { symbol }\end{array}$ & Parameter levels & Parameter value \\
\hline $\begin{array}{l}\text { Energy efficiency } \quad \text { of } \\
\text { enclosing structures }\end{array}$ & $P_{1}$ & $\begin{array}{l}\text { The deviation of the value of the } \\
\text { actual specific annual } \\
\text { consumption of energy resources } \\
\text { from - } 15 \text { inclusive to - } 30\end{array}$ & 54 \\
\hline $\begin{array}{l}\text { Physical deterioration of } \\
\text { structures }\end{array}$ & $P_{2}$ & Satisfactory, PD 21-30\% & 48.11 \\
\hline $\begin{array}{l}\text { Physical deterioration of } \\
\text { engineering networks and } \\
\text { equipment }\end{array}$ & $P_{3}$ & $\begin{array}{l}\text { Not quite satisfactory, PD 31- } \\
40 \%\end{array}$ & 43.56 \\
\hline Security level & $P_{4}$ & $\begin{array}{l}\text { The presence of one of the } \\
\text { complex security systems (fire } \\
\text { alarm) }\end{array}$ & 38 \\
\hline $\begin{array}{l}\text { The complexity of the } \\
\text { methods used to assess the } \\
\text { state of the residential house }\end{array}$ & $x_{5}\left(P_{5}\right)$ & Visual inspection & 43.56 \\
\hline Obsolescence of structures & $x_{6}\left(P_{6}\right)$ & Minor obsolescence, OS 0-15\% & 92 \\
\hline $\begin{array}{l}\text { Obsolescence of engineering } \\
\text { networks and equipment }\end{array}$ & $x_{7}\left(P_{7}\right)$ & $\begin{array}{l}\text { Perhaps the absence of a garbage } \\
\text { chute and telephone), OS } 0-15 \%\end{array}$ & 92 \\
\hline $\begin{array}{l}\text { Consumer quality of } \\
\text { residential house }\end{array}$ & $x_{8}\left(P_{8}\right)$ & $\begin{array}{l}\text { There are minor deviations from } \\
\text { the stated consumer quality }\end{array}$ & 43.56 \\
\hline
\end{tabular}

Calculate the potential for unscheduled overhaul:

$$
\begin{aligned}
P_{U . O .}(1)=\sum_{i=1}^{n} W_{i} & x_{i} \\
& =0,25 \cdot 54+0,19 \cdot 43,56+0,14 \cdot 43,56+0,13 \cdot 23+0,11 \cdot 43,56 \\
& +0,08 \cdot 92+0,06 \cdot 92+0,04 \cdot 43,56=50,27
\end{aligned}
$$

We define the psychophysical assessment of the resulting value of $P_{U . O}$.

The calculated value of 50.27 is in the range of 43.56 - 63 and corresponds to the psychophysical assessment of "Satisfactory".

\section{Conclusions}

As a result of the study, it was possible to form a method for estimating the initial state of a residential building based on a system of parameters, to form an organizational and technological model of a residential building in which unplanned major repairs are planned, and to describe a method for qualitative assessment of the organizational and technological moduli obtained. The developed model makes it possible to assess the degree of influence of a set of parameters on the performance of repair and construction work in apartment buildings. The developed private psychophysical scale allows giving a comprehensive assessment of the organizational and technological model. 


\section{References}

1. I. Abramov, Matec web of conferences, 193, pp. 7 (2018)

2. R. S. Fatullaev, Organizational and technological methods for unscheduled repair works. Components of scientific and technological progress, 3(33), 1722 (2017)

3. Khubaev, Organizatsionno-tekhnologicheskiye resheniya, vliyayushchiye na konechnyy potentsial proizvodstva betonnykh rabot $\mathrm{v}$ zimniy period. Perspektivy nauki (in Russian), 4(103), 57-61 (2018)

4. A. A. Lapidus, R. S. Fatullaev, Otsenka potentsiala provedeniya vneplanovykh remontnykh rabot mnogokvartirnykh zhilykh domov. Nauchnoye obozreniye (in Russian), 19, 10-13 (2017)

5. R. S. Fatullaev, Raschet potentsiala provedeniya vneplanovykh remontnykh rabot. Nauka i biznes: puti razvitiya (in Russian), 9(75), 34-40 (2017)

6. A. A. Lapidus, P. A. Govorukha, Organizational and technologic potential of setting of enclosing structures for residential buildings. International journal of applied engineering research, 10(20), 40946-40949 (2015)

7. Makarov, Iskusstvennaya neyronnaya set' dlya organizatsii i upravleniya stroitel'nym protsessom. Vestnik Belgorodskogo gosudarstvennogo tekhnologicheskogo universiteta im. V.G. Shukhova (in Russian), 4, 117-122 (2017)

8. T. Poznakhirko, A. Sergeev, Matec web of conferences, vol. 04063 (2016)

9. A. O. Khubaev, Organizatsionno-tekhnologicheskiye resheniya, vliyayushchiye na konechnyy potentsial proizvodstva betonnykh rabot $\mathrm{v}$ zimniy period. Perspektivy nauki (in Russian), 4(103), 57-61 (2018)

10. D. V. Topchiy, Ye. O. Kochurina, Povysheniye effektivnosti organizatsionnotekhnologicheskikh modeley proizvodstva rabot $\mathrm{v}$ usloviyakh stesnennoy gorodskoy sredy putem snizheniya vozdeystviya na podzemnyye sooruzheniya. Perspektivy nauki (in Russian), 1(100), 31-36 (2018)

11. R. S. Fatullaev, Formirovaniye algoritma kompleksnoy otsenki provedeniya vneplanovykh remontnykh rabot. Perspektivy nauki (in Russian), 9(96), 11-14 (2017)

12. B. F. Shirshikov, A. M. Slavin, V. S. Stepanova, S. O. Mikheyev, Minimizatsiya prodolzhitel'nosti vozvedeniya ob"yektov na osnove ispol'zovaniya informatsionno-dinamicheskikh setevykh modeley. Promyshlennoye i grazhdanskoye stroitel'stvo (in Russian), 2, 70-75 (2016)

13. R. S. Fatullayev, A. A. Lapidus, Organizatsionno-tekhnologicheskiye resheniya, obosnovyvayushchiye provedeniye vneplanovykh rabot po kapital'nomu remontu mnogokvartirnykh domov, (in Russian) 3(102), 304-307 (Vestnik MGSU, 2017)

14. A. A. Lapidus, A. O. Khubayev, Formirovaniye potentsiala organizatsionnotekhnologicheskikh resheniy ispol'zovaniya metodov betonirovaniya $v$ usloviyakh otritsatel'nykh temperatur. Nauka i biznes: puti razvitiya (in Russian), 11(77), 7-11 (2017) 
15. A. A. Lapidus, K. S. Tolstova, D. V. Topchiy, Formirovaniye grupp parametrov, vliyayushchikh na kriteriy dopustimosti sovmeshcheniya protsessov pri proizvodstve otdelochnykh rabot. Nauka i biznes: puti razvitiya (in Russian), 6(84), 18-22 (2018) 